\title{
Antibacterial Activity of Electrospun Silver Nitrate /Nylon 6 Polymeric Nanofiber Water Filtration Mats
}

\author{
Akram Raheem Jabur* Laith Kais Abbas** Saja Aqeel Moosa*** \\ *,*****Department of Materials Engineering / University of Technology \\ *Email: akram.jabut@gmail.com
}

(Received 13 July 2016; accepted 9 October 2016)

https://doi.org/10.22153/kej.2017.10.001

\begin{abstract}
Bacterial water pollution is a genuine general wellbeing concern since it causes various maladies. Antimicrobial nanofibers can be integrated by incorporating nanobiocides, for example, silver nanoparticles into nanofibers. Nylon 6 was dissolved in formic acid at a concentration of $\left(25 \mathrm{wt}\right.$. \%) and tough antibacterial $\left(\mathrm{AgNO}_{3} / \mathrm{Nylon}\right)$ nanofibers were produced utilizing electrospinning system. Polymer solution was tested before accomplishing electrospinning process to acquire its surface tension, electric conductivity and viscosity, where every one of those parameters increased relatively with increasing concentration of $\left(\mathrm{AgNO}_{3}\right)$ additions. SEM and EDX spectra were utilized to focus on the morphology, surface elemental membrane, fibers and porosize diameters. The resulted nanofiber membrane has an average fiber diameter of $139 \mathrm{~nm}$ for pure nylon 6 and $247 \mathrm{~nm}$ for $\left(1.2 \mathrm{wt}\right.$. \% $\left.\mathrm{AgNO}_{3} / \mathrm{Nylon}\right)$. The resultant polymer membrane was then tested for their ability to destroy microorganisms in water; antimicrobial tests showed that the prepared nanofibers have a high bactericidal effect against Escherichia Coli Bacteria with inhibition zone $(10 \mathrm{~mm})$ and antibacterial activity (99\%). Likewise, these results highlight the potential utilization of these nanofibrous mats as antimicrobial agents.
\end{abstract}

Keywords: Antibactrial, Electrospinning, Nanofiber, Water purification filters.

\section{Introduction}

The development of energy-efficient water treatment technology has become an important area of research as it offers a solution to the increasingly limited water supplies available to the world's growing population and industry [1-3]. Nanofibers have perfect filtration properties because of different polymers that can be used to produce nanofibers, functional molecules and chemical groups can be added to the nanofibers which made nanofibers applicable to sanitation and purification of water. Antimicrobial nanofibers synthesized by incorporating nanobiocides such as silver nanoparticles into the nanofibers (by reduction Silver Nitrate). The synthesis of nanofibers consists of metal nanoparticles is well investigated because of the benefits included with the joining of functional properties of metal nanoparticles with the widely applicable properties of nanofibers [4]. For a generation of nano-Ag-bearing nanofibres, silver can be added to the spinning solution either in form of nanoparticles [5] or as silverions which can be reduced to nano-Ag by a corresponding post-treatment [6, 7]. Reduction of ionic silver can be achieved (i) by subsequent UV-irradiation of the fiber webs, (ii) by the use of reducing agents [8] and (iii) by heat-treatment of the nanofibres [9].

Investigates in the previous years demonstrated that silver-containing electrospun nanofibers have pulled in consideration as another sort of antimicrobial material [10, 11]. Electrospinning process utilized for creation of nanofiber mat with high surface areas to volume aspect ratio, and high porosity. The process has appeared to be 
reasonable for production manufacturing of low-cost mass production [12, 13, 14]. Silver is extensively used as biocidal agent which is successful versus bacteria, fungi and viruses yet are non-harmful to man cells $[15,16]$. The electrospun nanofibers with high specific surface area and thinness combined with the biocidal effectivity of silver nanoparticles made an excellent antimicrobial material $[17,18]$. The reduction of aldehyde groups from $\left(\mathrm{AgNO}_{3}\right)$ forms a metallic silver. The formic acid goes about as the solvent for (Nylon 6) and a reducing agent for $\left(\mathrm{AgNO}_{3}\right)$. The (Nylon 6) solution in formic acid, trailed by silver nitrate were slowly included dark and opaque condition, with obvious visible bubbles have been appeared. The reaction mechanism in figure (1) can clarify the past segment. At the point when silver nitrate is included into the formic acid solution of (Nylon 6), it is reduced into metallic silver by the aldehyde group in the formic acid molecule. Simultaneously, the oxidation occurs in the aldehyde group and form carboxyl group. Then the carbonic acid form that is unsteady and rapidly dissociates into carbon dioxide and water [19]. The advantage of this system is the in situ stabilization of silver nanoparticles. Initially, ions are reduced to metallic silver, immediately atoms are aggregated into clusters. These clusters have very small size and high surface energy, which leads them to form larger particles. Usually a surfactant agent is added to stabilize silver and avoid further aggregation [20, 21]. When antimicrobial agents are needed, silver is considered best material, and its forms are a strong antimicrobials against diverse bacterial kinds. The precise mechanism of how silver take part in the distortion of bacteria is regrettably yet unclear. Silver nanoparticles adhere to the microbial cell membrane where it interacts with sulfur-containing proteins. Nanoparticles can also penetrate the cell membrane, where it interacts with phosphorous-containing DNA and attack thiol groups of respiratory chain enzymes, inhibiting cell division and respiration, finally leading to cell death [22, 23]. However, mostly it is supposed that sliver basically makes denaturation and oxidation for cell organelles which drive to suppress the cell segmentation. As Known, the inhibition zones formed near the contact part when the critical amount of antibacterial agents in touch with bacterial strains[24].

The object of this study is to prepare antimicrobial (Nylon 6) nanofibers containing silver nanoparticles by electrospinning technique. The solvent and polymer in this research act as reducing and a stabilizing agent, respectively.

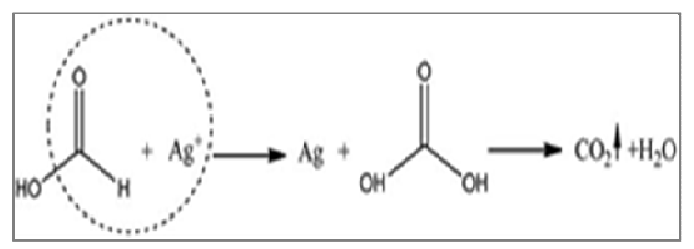

Fig. 1. Chemical mechanism of silver reduction by formic acid [18].

Nylon 6 is chosen due to it is one of the most used conventional fibers materials. Finally, demonstrating Antibacterial properties for use in water disinfection (Escherichia coli $(E$. Coli)) was chosen in this study as indicators of fecal contamination.

\section{Experimental Part 2.2. Materials}

Nylon 6, formic acid, and silver nitrate (AgNO3) were bought from (Sigma-Aldrich Co. (USA)). All materials were utilized without further purification.

\subsection{Preparation of Nylon 6/AgNO3 Electrospinning Solution}

Nylon 6 was dissolved in formic acid at a concentration of ( $25 \mathrm{wt} . \%)$ and was stirred at $\left(30-40{ }^{\circ} \mathrm{C}\right.$ ) for (3) hrs to acquire a transparent homogeneous solution. The solution was then cooled to room temperature under stirred, and a specific amount of AgNO3 (0.2 to1.2 wt\% in solution) was included. The solution was avoided from light and stirred under room temperature for (3) hrs to insure the complete reduction of (AgNO3).

\subsection{Electrospinning}

The prepared electrospun solution was gathered in $(10 \mathrm{ml})$ syringe furnished with a (22 gauge) stainless steel needle tip. The electrospinning process was conveyed at voltage $(25 \mathrm{KV})$, flow rate $(0.5 \mathrm{ml} / \mathrm{hr}),(22)$ gauge $(0.7 \mathrm{~mm})$ needle of electrospinning, and $(15 \mathrm{~cm})$ separation distance between electrode. The electrospinning process took four hour time and these parameters will be fixed for every solution in this work. The electrospinning process was carried out by a (Bio-electrospinning/ Electrospray system ESB-200, provided by Nano NC, South Korea), as shown in Figure (2). 


\subsection{Characterizations}

\section{- Characterization of polymer solution}

Before electrospinning and (SEM, EDX) of membrane after spinning process: Pure and $\left(\mathrm{AgNO}_{3}\right.$ /Nylon 6) polymeric Solution viscosity were measured by a Viscometer of type (DV-II- pro)
Brook, Solution electrical conductivity was measured using the electrical conductivity device of model ( $\mathrm{C}$ and 7110 inolab) and Surface tension also measured using a Surface Tensiometer model (JYW-200ALARYEE TECHNOLOGY CO).

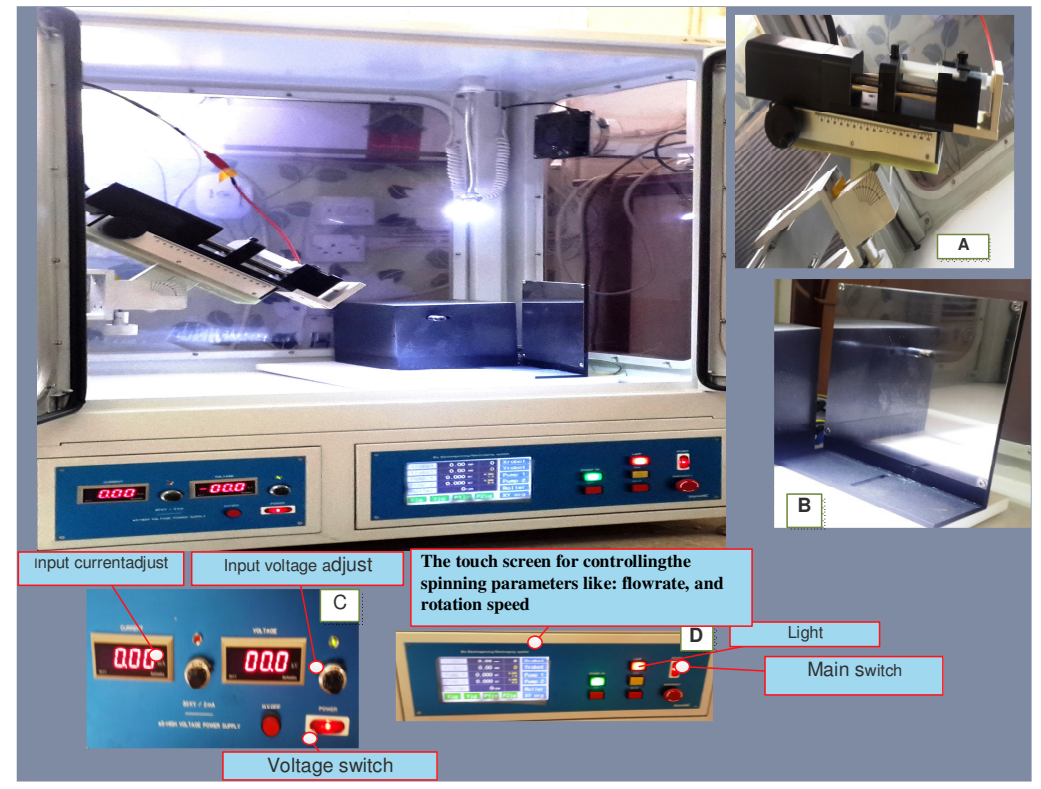

Fig. 2. Electrospinning device: a- syringe pump instruction, b- collector plate, c- power supply, d-touch control Board.

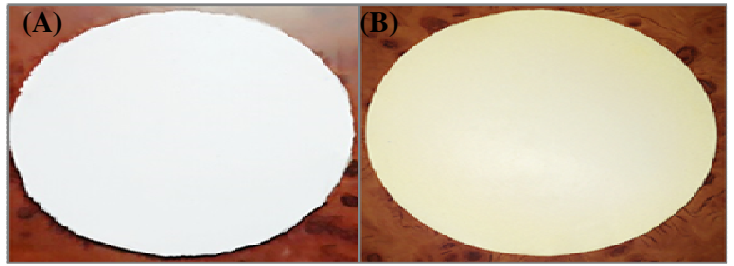

Fig. 3. Photographs of (Nylon 6) nanofibrous web (A) Without $\left(\mathrm{AgNO}_{3}\right)$ and $(\mathrm{B})$ Nylon 6 with $\left(\mathrm{AgNO}_{3}\right)$.

The surface morphology of nanofibers and measurement for the overages fibers diameters and process was observed using scanning electron microscope (Model: VEGA3 LM -TESCAN)), by mode of low variable pressure, which must be enough and not need any more of sample gold ion sputtering coating to a chive conductivity surface for (SEM) test.

\section{- Antibacterial Assessment Assay:}

\section{A. Antibacterial Activity Test (Disc Diffusion Method):}

The bacteria were grown aerobically in nutrient broth at $\left(37^{\circ} \mathrm{C}\right.$ for $\left.12 \mathrm{hrs}\right)$ [25]. The cells were washed and suspended in distilled water, reaching the final concentration of $\left(10^{6} \mathrm{CFU} / \mathrm{mL}\right)$. The antimicrobial susceptibility of (Nylon 6 nanofibers / additives) was evaluated using the disc diffusion method. Muller - Hinton agar was prepared from a commercially available dehydrated medium according to manufacturer's instructions. The dried surface of Muller Hinton agar plate was inoculated with E.coli by swabbing over entire the sterile agar surface. Two forms of sterilized samples of nanofiber membrane (one containing additive and one without additive, used as control) were cut into small standard circles $(6 \mathrm{~mm}$ in diameter) for each circle and placed on the surface of the inoculated media. The plates were incubated at $\left(37^{\circ} \mathrm{C}\right.$ for 24 hours). Following incubation plates were examined in order to identify zones of on growth (halos around the fragments) characteristic for antibacterial activity. 


\section{B. Measuring Antibacterial Activity by the Optical Density Method:}

The antibacterial activity of electrospun nanofibers membrane was tested by immobilizing nanofiber onto filters of a Millipore, under vacuum filtration. A test water sample was prepared by inoculating $\left(1 * 10^{8}\right.$ cells $\left./ \mathrm{ml}\right)$ Escherichia Coli into $(250 \mathrm{ml})$ of sterile normal saline water sample of $(0.85 \% \mathrm{NaCl})$ in $(100 \mathrm{~mL})$ distilled water. Water samples were then filtered through the membrane. After this step the optical density of the solution was measured by a UV spectrophotometer (UV1800 spectrophotometer, Shimadzu) the number of bacteria was indirectly measured by optical density at $(450 \mathrm{~nm})$ in an ultraviolet (UV) -visible spectrometer and the antibacterial activity was calculated by the following equation:

Antibacterial activity $=(\mathrm{A}-\mathrm{B}) / \mathrm{A} \times 100 \%$

Where $A$ : the numbers of surviving cells in the control and B: the numbers of surviving cells in the test samples [27].

\section{Results and Discussion}

Figure (4), shows the viscosities of electrospinning solutions with different $\left(\mathrm{AgNO}_{3}\right)$ precursor concentration. It is clear shows viscosity of solution increased with increasing $\left(\mathrm{AgNO}_{3}\right)$ concentration. As shown in figure (7) every (Nylon) molecule layer binds with a silver nanoparticle because of the highest particle surface energy. As its discussed before, the formation of intermolecular interactions with chains in the solution from the (Nylon 6) molecule chains on the surface of silver nanoparticles is responsible for the viscosity increase [28, 29].

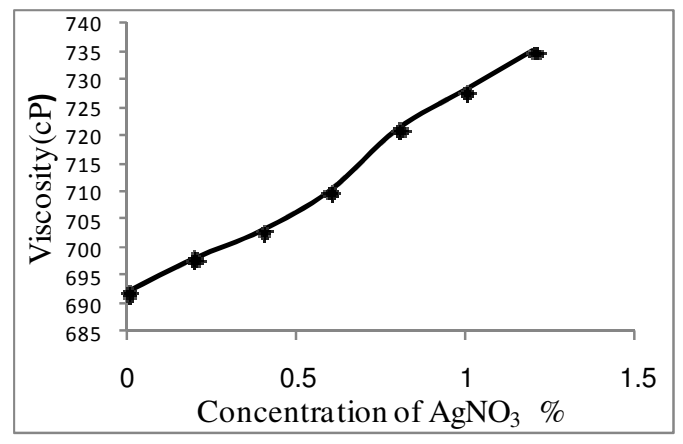

Fig. 4. Effect the $\left(\mathrm{AgNO}_{3}\right)$ on viscosity of (Nylon 6).

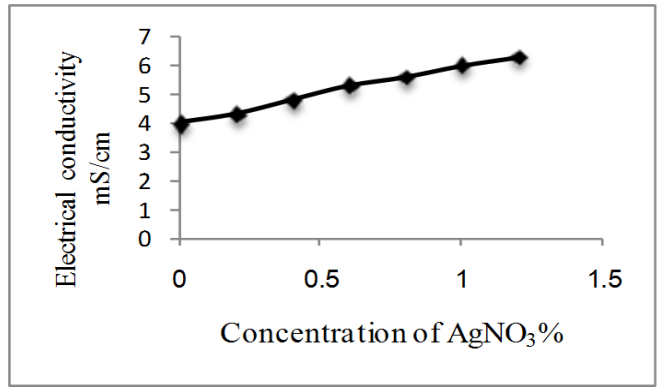

Fig. 5. Effect the $\left(\mathrm{AgNO}_{3}\right)$ on Electrical Conductivity of (Nylon 6).

Because of the presence of the $\left(\mathrm{Ag}^{+}\right.$and $\mathrm{NO}^{-3}$ ) ions the conductivity of the solution increase. Figure (5) shows the increase in the solution conductivity with increasing $\left(\mathrm{AgNO}_{3}\right)$ concentration.

The surface tension of the electrospinning solution was increase due to the viscosity of solution increase. The effect of $\left(\mathrm{AgNO}_{3} / \mathrm{Nylon}\right.$ 6 ) on surface tension was showed in figure (6).

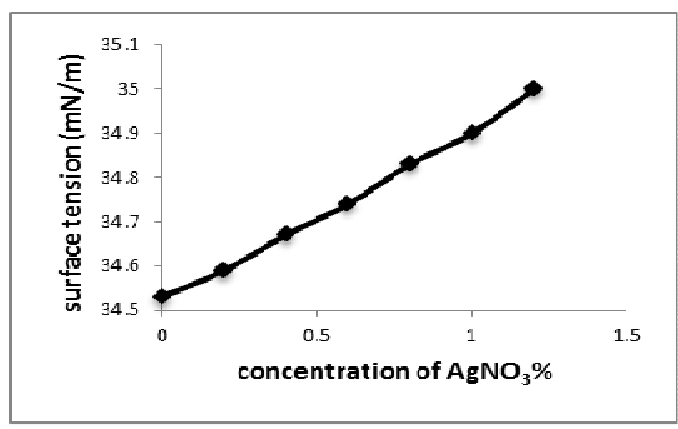

Fig. 6. Effect the $\left(\mathrm{AgNO}_{3}\right)$ on surface tension of (Nylon 6).

Figure (7) shows that formic acid acts as a reducing agent in the reduction reaction of the (Nylon 6) molecule chain solution. As soon as the silver nanoparticles are created, (Nylon 6) molecules on the particle surface stabilize them in the nanosize and prevent them from more aggregating by decreasing their surface activity. Nylon 6 molecules work as a matrix of electrospun nanofibers and a stabilizing agent of silver nanoparticles. 


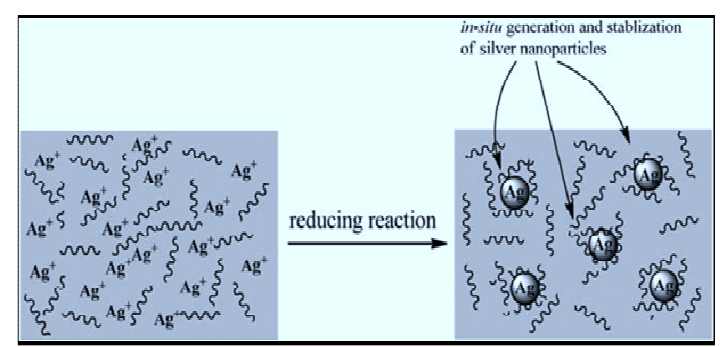

Fig. 7. Silver nanoparticles formation and stabilization by the in situ generation mechanism [18].
Figure (8-A) shows the (SEM) image of (Nylon 6) electrospun nanofibers mats, the nanofibers looks continues and smooth fibrous structure and homogeneous morphology, with an average diameter (139 $\mathrm{nm}$ ) obtained from the histogram drawn from (SEM) image analysis and calculated and shown in figure (8-b) for average fiber diameters and figure (8-c) for pore size. Figure (8-a) shows (Nylon 6) nanofibers
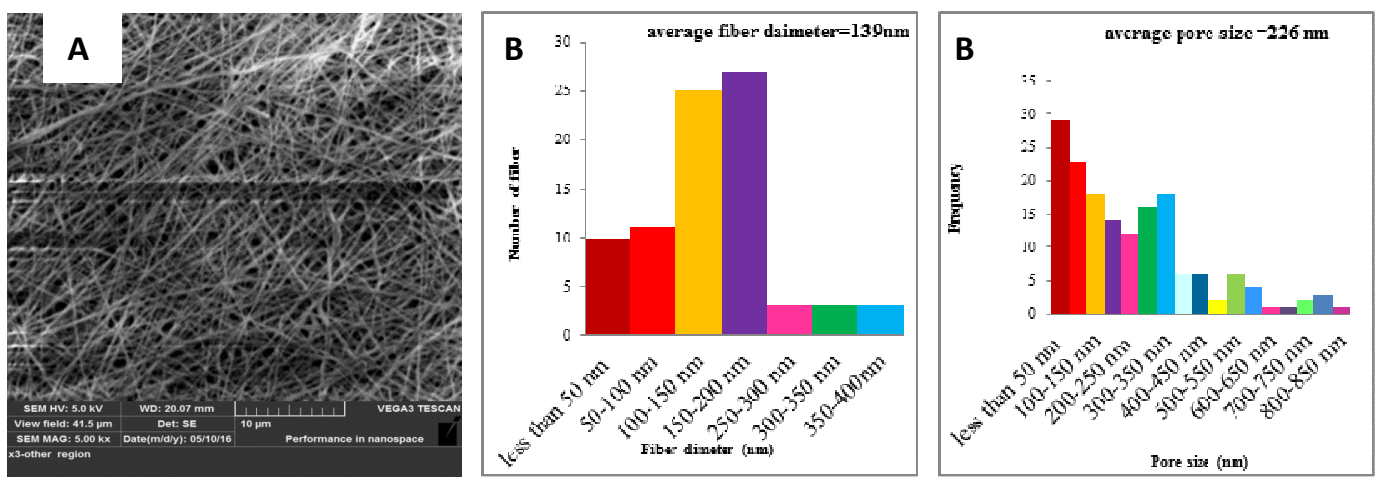

Fig. 8. (A) SEM image of pure (Nylon 6) nanofibers membrane, (B) diameter distribution and (C) pore size distribution.
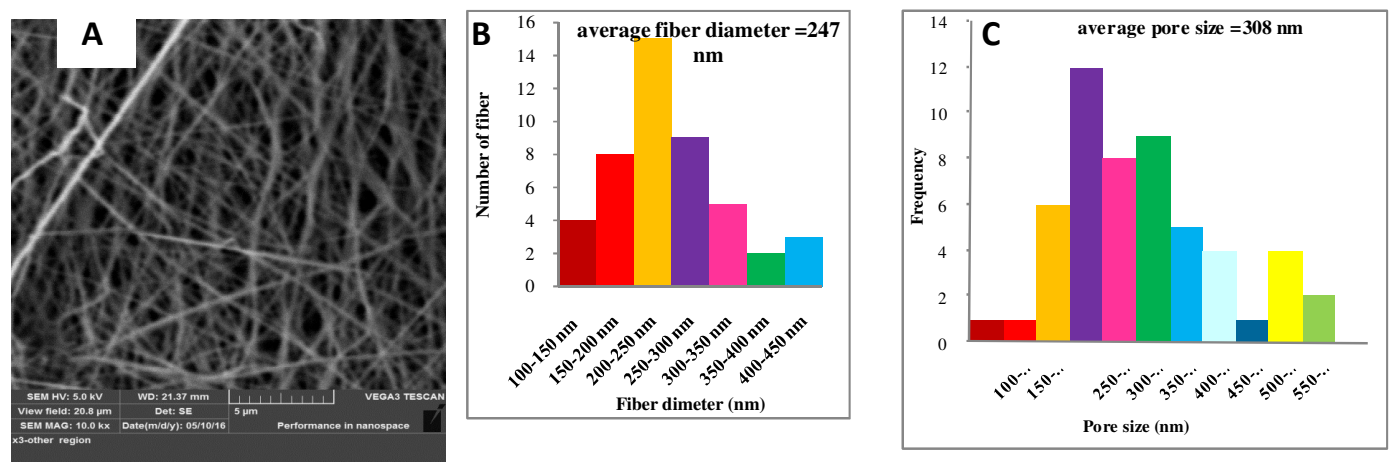

Fig. 9. (A) $\mathrm{SEM}$ image of $\left(\mathrm{AgNO}_{3} / \mathrm{Nylon} 6\right)$ nanofibers membrane, (B) diameter distribution and (C) pore size distribution.

With resulted a smooth, free beads structures and homogeneous morphology. The (Nylon 6) nanofibers maintained its morphology upon loading with $\left(\mathrm{AgNO}_{3}\right)$, Figure (9-A) with average nanofiber diameters $(247 \mathrm{~nm})$.

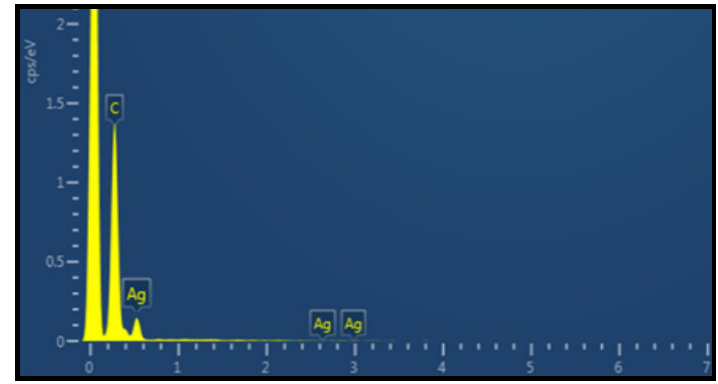

Fig. 10. EDX spectrum result of $(0.4 \%$ AgNO3/Nylon 6). 
A high magnification (SEM) image of $\left(\mathrm{AgNO}_{3} / \mathrm{Nylon} 6\right)$ with the (EDX) spectrum analysis of electrospun membrane suggests the chemical composition and show (Ag (peak)) due to addition $\left(\mathrm{AgNO}_{3}\right)$ reduced to (Ag-NPs). Figure (10) EDX spectra of $\left(\mathrm{AgNO}_{3} / \mathrm{Nylon} 6\right)$ which confirm the existence of (Ag-NPs) and formed into fibers. Our process to fabricate the (Ag) nano purification (Nylon fibers) to insure that the formed (Ag-NPs) will be inside the polymeric fibers and never at its surfaces to avoid removing its from fibers at application condition as a result of water or any fluid flow through for water purifications.

\section{Microbiological Study}

Figure (11) shows the incubated petri plates of (E. coli) grown in presence of circular nanofiber mats after $24 \mathrm{hrs}$. From that figure (11), generation of clear zone surrounds circular mat contains silver-nanoparticles (AgNO3), where in the (Nylon 6) nanofiber membranes these zones are absent. The creation of clear zones surrounds the nanofiber mat is an indicator for inhibition of bacteria colonies near the nanofiber mat edges. Mainly, because of the existence of silver in the nanofiber mat, it may kill the microorganism that surrounds the mat which results in formation of clear circular zones.

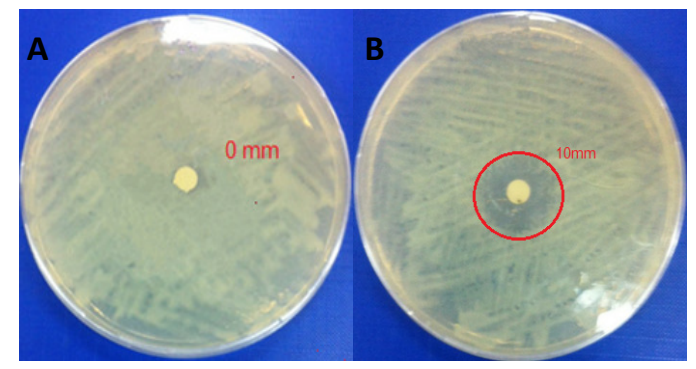

Fig. 11. Antimicrobial activities of (Nylon 6) nanofibers against Escherichia coli. (a) Missing the inhibition zone in plain (Nylon 6), (b) (1.2 $\left.\% \mathrm{AgNO}_{3}\right)$, where the inhibition zone is visible in (Nylon 6) embed $\left(\operatorname{AgNPs}\left(\mathrm{AgNO}_{3}\right)\right)$.

Quan Shi et al.[19], shows that silver nanoparticles loaded nylon produced in one stage process can liberate a appropriate amount of silver to offer excellent antibacterial activity. Antibacterial activity of nylon 6 loaded silver nanoparticles $\left(\mathrm{AgNO}_{3}\right)$ showed an increase in the inhibition zone as the $\left(\mathrm{AgNO}_{3}\right)$ increase due to increase (Ag-NPs) as the result of antibacterial activity test Figure (12).

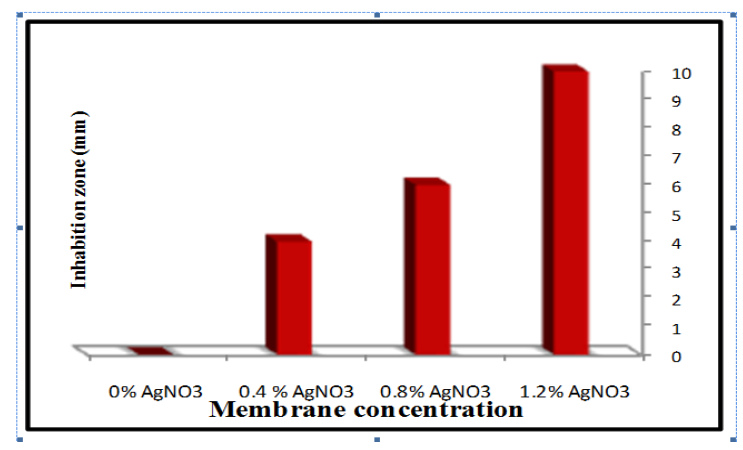

Fig. 12. Effect of $\left(\mathrm{AgNO}_{3}\right)$ on antibacterial activity of (Nylon 6) by measuring an inhibition Zone E.Coli Medium.

Antibacterial activity of $\left(\mathrm{AgNO}_{3} / \mathrm{Nylon} 6\right)$ was also proven by optical density. Optical density is measured by using a spectrophotometer. Light scattering rises with the increase in cell number. When light is passed through bacterial cell suspension, light is scattered by the cells and transmission decays. At a particular wavelength, light optical density is proportional to the cell concentration of micro-organisms present in the suspension. This is a nondestructive method that is also very simple, rapid and accurate. Both live and dead cells are, however, able to scatter light and, therefore, both are counted [26].

As show in (SEM) image of the surface of nanofiber membrane and illustrate dendritic shape the cluster (live or dead) on surface of the membrane Figure (13). Which indicate that the filter can stop bacteria from passing through, while the formation of bacteria as a cluster on the surface of the filter and prevent it from penetrating through the nanofiber membrane. Figure (14) shows the influence of the $\left(\mathrm{AgNO}_{3}\right)$ concentration on antibacterial activity. The antibacterial activity the electrospun nanofiber mats increased by increasing the $\left(\mathrm{AgNO}_{3}\right.$ wt.\%) concentration, Which approach to about $(<99 \%$ $\pm 0.5)$ for $E$. coli at concentrations of (1.2 wt.\% $\mathrm{AgNO}_{3}$ ) in (Nylon 6). An antibacterial properties has been found on nylon 6 nanofibers while the nylon nanofibers/Ag NPs showed excellent antibacterial activities against E. coli (Gramnegative) and Staphylococcus aureus (Grampositive) bacteria as provided by M. Montazer [30]. 


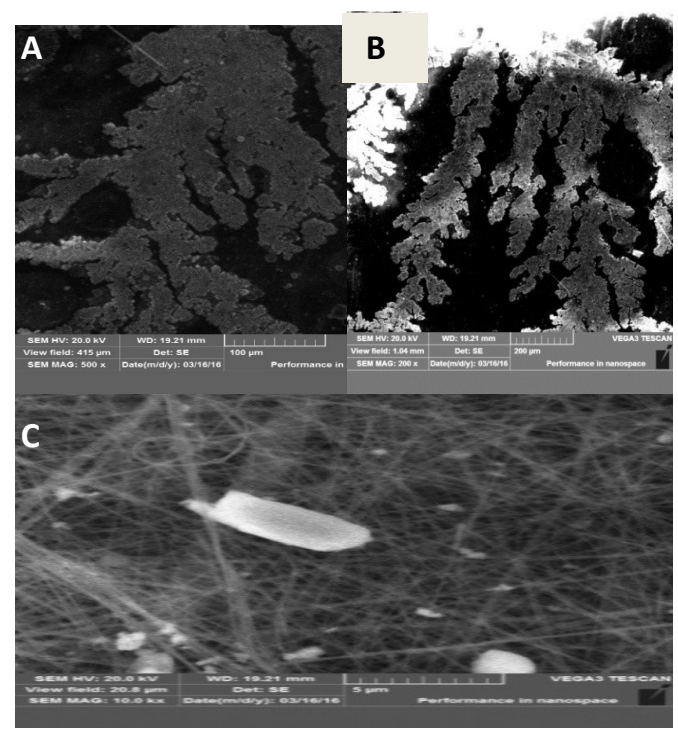

Fig. 13. SEM of membrane after exposing to bacteria where the bacteria cluster (a) on the membrane surface as a dendritic shape colony (b) and (c) shows how fiber captures the bacteria.

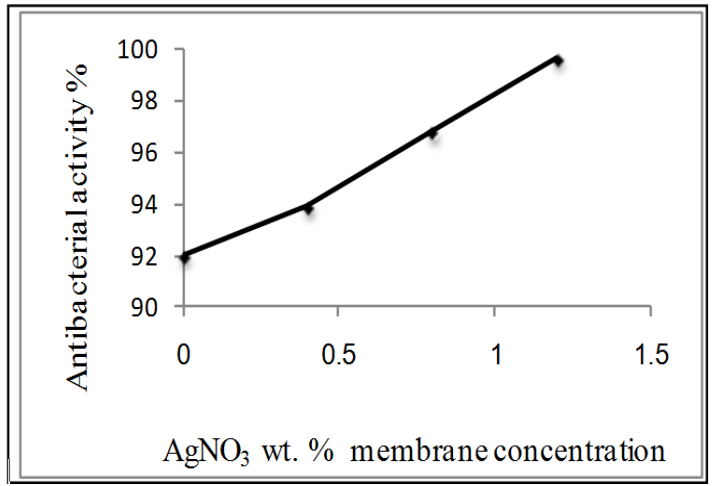

Fig. 14. Antibacterial activities at different $\left(\mathrm{AgNO}_{3} /\right.$ Nylon $\left._{6}\right)$ membrane concentration.

\section{Conclusions}

This article portrays a simple way to deal with fabricated (Ag nanoparticles inside nanopolymeric nylon fibers $\left(\mathrm{AgNO}_{3}\right)$ by formic acid reduction), silver nano-particle loaded (Nylon 6) Nano fibers by means of a one-stage electrospinning process. This process includes silver nanoparticles formation and stabilization by the in situ generation Mechanism where the solvent work as reducing agent and polymer matrix act as stabilizing agent. Other than the electrospinning solution, this technique does not require extra reducing/protecting agents or (thermal/illumination) treatment. The in situ formation of nanoparticles and the stabilizing mechanism of (Nylon 6) molecules result in a restricted size of silver nanoparticles and uniform scattering of silver nanoparticles in the nanofiber mat, as tested by (SEM) and (EDX). Antibacterial measures demonstrate these nanofibers have more than $(99.6 \%)$ antibacterial activity to $E$. coli.

\section{References}

[1] J. Theron, JA. Walker, TE. Cloet, "Nanotechnology and water treatment applications and emerging opportunities", Crit. Rev. Microbiol. Vol. 34, (2008), pp: 43-69.

[2] N. Savage, M. S. Diallo, "Nanomaterials and water purification: Opportunities and challenges" J. Nanopart Res, Vol. 7, (2005), pp: 331-342.

[3] J. Bottero, J. Rose, M. R Wiesner., "Nanotechnologies: Tools for sustainability in a new wave of water treatment processes", Integrated Environ Assess Manag, Vol. 2, (2006), pp: 391-395

[4] LF. Zhang, JE. Luo, TJ. Menkhaus, H. Varadaraju, YY. Sun, H. Fong, "Antimicrobial nano-fibrous membranes developed from electrospun polyacrylonitrile nanofibers", J. Memb Sci, (2011), Vol. 369, pp: 499-505.

[5] S. Park, H. Bae, Z. Xing, O. Kwon, M. Huh, I. Kang, "Preparation and properties of silver-containing Nylon 6 nanofibers formed by electrospinning", J Appl Polym Sci, Vol. 112, No. (4), (2009), pp: 23202326.

[6] [H. Jeon, J. Kim, T. Kim, J. Kim, W. Yu , J. Youk , "Preparation of poly(ecaprolactone)- based polyurethane nanofibers containing silver nanoparticles", Appl Surf Sci; Vol. 254, No.(18), (2008), pp: 5886-5890.

[7] A. Kumar, R. Chhatra, P. Pandey "Synthesis of click bile acid polymers and their application in stabilization of silver nanoparticles showing iodide sensing property", Org Lett; Vol. 12, No.(1), (2010), pp: 24-31.

[8] [8]. N. Luong, Y. Lee, J. Nam, "Highlyloaded silver nanoparticles in ultrafine cellulose acetate nanofibrillar aerogel", Eur Polym J, Vol. 44, No.(10), (2008), pp: 31163121.

[9] V. Sharma, R. Yngard, Y. Lin "Silver nanoparticles: green synthesis and their antimicrobial activities". Adv Colloid Interface; 145(1-2), (2009), pp:83-96. 
[10] X. Xu, Q. Yang, Y. Wang, H. Yu, X. Chen, $\mathrm{X}$. Jing, "Biodegradable electrospun poly(L-lactide) fibers containing antibacterial silver nanoparticles", Eur Polym J, Vol. 42, No.(9), (2006), pp: 20812087.

[11] J. Kim, E. Kuk, K. Yu, J. Kim, S. Park, Lee H. , "Antimicrobial effects of silver nanoparticles. Nanomed Nanotechnol", Vol. 3, No.(1), (2007), pp: 95-101.

[12] Akram R. Jabur, Laith K. Abbas, Safa M. Muhi Aldain, "Ambient Temperature Affect the Pore size of PVA Nanofibers Tissues", The 5th International scientific Conference on Nanotechnology \& Advanced Materials Their Applications, (ICNAMA 2015) 3-4 Nov, Eng.\&Tech. Journal. Vol. 33, Part (B), No.6, (2015).

[13] Akram R. Jabur, Fadhil A. Chayad, Noor M. Jalal, "Fabrication and Characterization of Nylon 6/ MWCNTs Conductive Polymer by Electrospinning Technique", International Journal of Thin Films Science and Technology, Int. J. Thin. Fil. Sci. Tec. 5, No. (2), pp:1-9, (2016).

[14] Akram R. Jabur, Laith K. Abbas, Safa M. MuhiAldain, "The Effects of Operating Parameters on The Morphology of Electrospun Polyvinyl alcohol Nanofibers", The International 3rd. Scientific Conference of the College of Science, Journal of University of Kerbala Vol. 36, (2015).

[15] M. Rai, A. Yadav, A.Gade, "Silver nanoparticles as a new generation of antimicrobials", Biotechnol Adv, Vol. 27, No. (1), (2009), pp: 76-83.

[16] Q. L.Feng, J. Wu, G. Q. Chen, Cui F. Z., Kim T. N., Kim J. O. A, "Mechanistic study of the antibacterial effect of silver ions on Escherichia coli and Staphylococcus aureus", J. Biomed Mat Res, Vol. 52, (2000), pp: 662-668.

[17] R. Pim-on , P. Nuttaporn , S. Pitt , "Preparation, characterization and antibacterial properties of electrospun polyacrylonitrile fibrous membranes containing silver nanoparticles", J. Appl Polym Sci, Vol. 116, No.(4), (2010), pp: 1967-76.

[18] Castellano J, Shafii S, Ko F, Donate G, Wright T, Mannari R, "Comparative evaluation of silver-containing antimicrobial dressings and drugs", Int Wound; Vol. 4, No.(2), (2007), pp: 114-22.

[19] Q. Shi, N. Vitchuli, J. Nowak, J. Noar, J.M. Caldwell, F. Breidt, M. Bourham, M.
McCord and X. Zhang, "One-step synthesis of silver nanoparticle-filled nylon 6 nanofibers and their antibacterial properties", J. Mater. Chem., Vol. 21, (2011), pp: 10330-10335.

[20] H. Wang, X. Qiao, J. Chen and S. Ding, Colloids Surf., A., "Preparation of silver nanoparticles by chemical reduction method", J. Mater. Chem., Vol. 256, (2005), pp: 111-115.

[21] S. W. Kang and Y. S. Kang, "Silver nanoparticles stabilized by crosslinked poly(vinyl pyrrolidone) and its application for facilitated olefin transport", J. Colloid Interface Sci., Vol. 353, (2010), pp: 83-86.

[22] L. De Santa Maria, A. Santos, P. Oliveira, Barud H, Messaddeq Y, Ribeiro S., "Synthesis and characterization of silver nanoparticles impregnated into bacterial cellulose", Mater Lett; Vol. 63, No.(9-10), (2009), pp: 797-806.

[23] JP. Chen, Chiang Y. Bioactive, "Electrospun silver nanoparticles-containing polyurethane nanofibers as wound dressings", J. Nanosci Nanotechno, Vol. 10, (2010), pp: 7560-7564.

[24] FA. Sheikh., "Electrospun antimicrobial polyurethane nanofiber containing silver nanoparticles for biotechnological applications", Macromolecular Research, Vol. 17, No. (9), (2009), pp: 688-696.

[25] S. Pal, YK. Tak , JM Song , "Does the antibacterial activity of silver nanoparticles depend on the shape of the nanoparticle? A study of the Gram negative bacterium Escherichia coli. Applied and Environmental Microbiology", Vol .73, No. (6), (2007), pp: 1712-1720.

[26] B. Zhong Tang, A. S. Abd-El-Aziz, Stephen L. Craig, Duke, Jianhua Dong, Toshio Masuda, And Christoph Weder, "Polymeric Materials with Antimicrobial Activity From Synthesis to Applications", RSC Polymer Chemistry Series, No.(10), (2014), ISSN: 2044-0790 pp: 3.

[27] B.Son, B.Y.l Yeom, S. H. Song, C.S. Lee, T.S.g Hwang, "Antibacterial Electrospun Chitosan/Poly(vinyl alcohol) Nanofibers Containing Silver Nitrate and Titanium Dioxide", Journal of App.Polymer Science, Vol. 111, (2009), pp: 2892-2899.

[28] Q. Shi, N. Vitchuli, L. Ji, J. Nowak, M. McCord, M. Bourham, X. Zhang, "A facile approach to fabricate porous nylon 6 nanofibers using silica nanotemplate", J. Appl. Polym. Sci., (2011), Vol. 120, pp: 425-433. 
[29] Fadhil A. Chayad, Akram R. Jabur, Shaimaa J. Kareem, "The microstructure and characterization of nickel ferrite nanofibers", Advances in Natural and Applied Sciences, Vol. 10, No.(8), june (2016), pp: 48-55.
[30] M. Montazer,

S. B. Malekzadeh" Electrospun antibacterial nylon nanofibers through in situ synthesis of nanosilver: preparation and characteristics", Journal of Polymer Research, (2012), 19: 9980. doi:10.1007/s10965-012-9980-8. 


\section{الفعالية المضادة للبكتريا لحصيرة الالياف الناتوية لترشيح المياه البوليمرية المصنعة من نترات فضة. نايلون

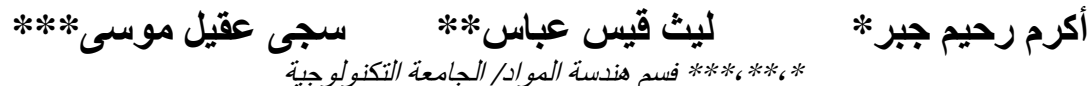

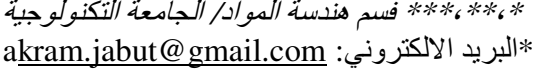

الخلاصة

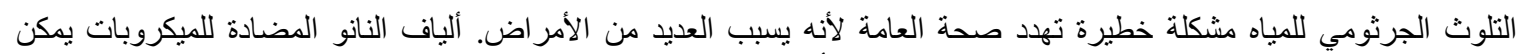

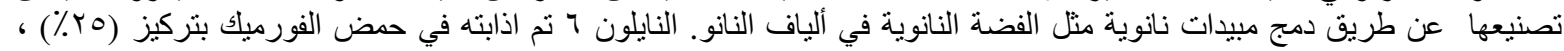

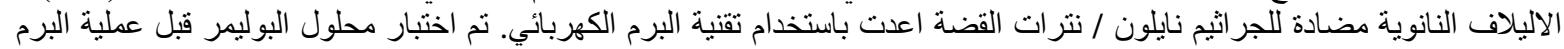

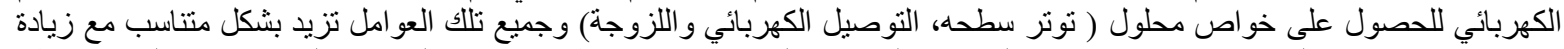

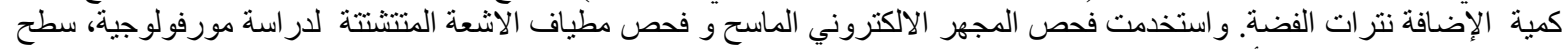

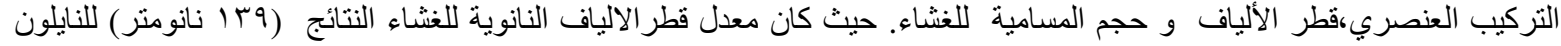

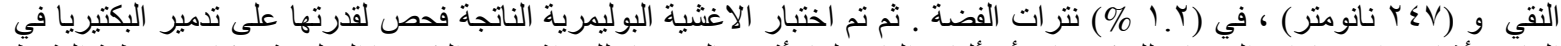

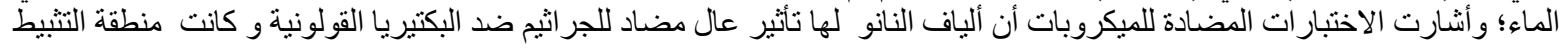

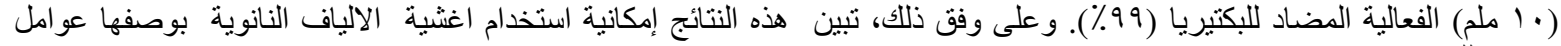

